\title{
Large Greenhouse Gas Emissions from a Temperate Peatland Pasture
}

\author{
Yit Arn Teh, ${ }^{1,2 *}$ Whendee L. Silver, ${ }^{2}$ Oliver Sonnentag, ${ }^{2}$ Matteo Detto, ${ }^{2}$ \\ Maggi Kelly, ${ }^{2}$ and Dennis D. Baldocchi ${ }^{2}$
}

${ }^{1}$ Environmental Change Research Group, School of Geography \& Geosciences, University of St Andrews, St Andrews KY16 9 AL, Scotland, UK; ${ }^{2}$ Department of Environmental Science, Policy, and Management, University of California, Berkeley, California 94702, USA

\begin{abstract}
Agricultural drainage is thought to alter greenhouse gas emissions from temperate peatlands, with $\mathrm{CH}_{4}$ emissions reduced in favor of greater $\mathrm{CO}_{2}$ losses. Attention has largely focussed on $\mathrm{C}$ trace gases, and less is known about the impacts of agricultural conversion on $\mathrm{N}_{2} \mathrm{O}$ or global warming potential. We report greenhouse gas fluxes $\left(\mathrm{CH}_{4}, \mathrm{CO}_{2}, \mathrm{~N}_{2} \mathrm{O}\right)$ from a drained peatland in the Sacramento-San Joaquin River Delta, California, USA currently managed as a rangeland (that is, pasture). This ecosystem was a net source of $\mathrm{CH}_{4}\left(25.8 \pm 1.4 \mathrm{mg} \mathrm{CH}_{4}-\mathrm{C} \mathrm{m}^{-2} \mathrm{~d}^{-1}\right)$ and $\mathrm{N}_{2} \mathrm{O}\left(6.4 \pm 0.4 \mathrm{mg} \mathrm{N}_{2} \mathrm{O}-\mathrm{N} \mathrm{m}^{-2} \mathrm{~d}^{-1}\right)$. Methane fluxes were comparable to those of other managed temperate peatlands, whereas $\mathrm{N}_{2} \mathrm{O}$ fluxes were very high; equivalent to fluxes from heavily fertilized agroecosystems and tropical forests. Ecosystem scale $\mathrm{CH}_{4}$ fluxes were driven by "hotspots" (drainage ditches) that accounted for less than $5 \%$ of the land area but more than $84 \%$ of emissions. Methane fluxes were
\end{abstract}

unresponsive to seasonal fluctuations in climate and showed minimal temporal variability. Nitrous oxide fluxes were more homogeneously distributed throughout the landscape and responded to fluctuations in environmental variables, especially soil moisture. Elevated $\mathrm{CH}_{4}$ and $\mathrm{N}_{2} \mathrm{O}$ fluxes contributed to a high overall ecosystem global warming potential (531 $\mathrm{g} \mathrm{CO}_{2}$-C equivalents $\mathrm{m}^{-2} \mathrm{y}^{-1}$ ), with non- $\mathrm{CO}_{2}$ trace gas fluxes offsetting the atmospheric "cooling" effects of photoassimilation. These data suggest that managed Delta peatlands are potentially large regional sources of greenhouse gases, with spatial heterogeneity in soil moisture modulating the relative importance of each gas for ecosystem global warming potential.

Key words: methane; nitrous oxide; carbon dioxide; global warming potential; drained temperate peatland; management; agricultural conversion; Sacramento-San Joaquin Delta.
Received 30 July 2010; accepted 22 December 2010;

published online 1 February 2011

Author Contributions: Y. A. Teh: conceived of and designed the experiment, collected the static flux chamber and environmental measurements, analyzed the entire data set, and took the principal role in writing the manuscript; W. L. Silver: provided extensive input into the conception and design of the experiment, and made substantial contributions to the written text; O. Sonnentag: analyzed the remote sensing imagery and was responsible for calculating the spatially weighted extrapolations of static chamber fluxes; M. Detto: performed the micrometeorological measurements and took the principal role in analyzing and interpreting the eddy covariance data; M. Kelly: assisted in the analysis and interpretation of the remote sensing imagery; D. D. Baldocchi: coordinated overall research efforts at the study site, provided extensive input into the experimental design, assisted in the analysis and interpretation of the eddy covariance data, and was also closely involved in editing the manuscript.

*Corresponding author; e-mail: yat@st-andrews.ac.uk

\section{INTRODUCTION}

Peatlands constitute one of the largest terrestrial C-stores, accounting for at least one-third of the global soil C pool (Limpens and others 2008). Peatlands are found at all latitudes, and include brackish coastal estuaries, freshwater river deltas, tropical swamps, inland bogs, and fens (Dise 2009). Under natural, unmanaged conditions, peatlands are sinks for atmospheric $\mathrm{CO}_{2}$, because waterlogged soil conditions inhibit aerobic decomposition, favoring the accumulation of soil organic matter (Dise 2009). However, peatlands do not always 
exert a net "cooling" effect on the atmosphere because they also emit non- $\mathrm{CO}_{2}$ greenhouse gases (Dise 2009; Frolking and Roulet 2007). For example, peatlands are one of the largest natural sources of atmospheric $\mathrm{CH}_{4}$, a greenhouse gas approximately 25 times more effective than $\mathrm{CO}_{2}$ in absorbing long-wave radiation in the atmosphere, and responsible for $20 \%$ of current climate forcing (Forster and others 2007). Recent reports also suggest that peatlands may emit significant quantities of $\mathrm{N}_{2} \mathrm{O}$, a gas with 298 times the global warming potential of $\mathrm{CO}_{2}$, although the dynamics and magnitude of these fluxes are poorly characterized (Jungkunst and Fiedler 2007; Repo and others 2009).

Studies of peatland greenhouse gas exchange have focussed on natural or unmanaged environments, with fewer studies investigating greenhouse gas dynamics in managed systems (Limpens and others 2008; Waddington and Price 2000). The majority of these studies have in turn concentrated on greenhouse gas fluxes from northern (that is, boreal, sub-arctic, arctic) ecosystems, rather than on temperate or tropical ones (Limpens and others 2008; Waddington and Roulet 1996; Zona and others 2009; Hendriks and others 2007). Temperate peatlands are likely to have greater overall trace gas fluxes than their northern counterparts because they experience warmer conditions and longer growing seasons (Carroll and Crill 1997; Fiedler and others 2005; Fowler and others 1995b; Hendriks and others 2007; Jungkunst and Fiedler 2007). Moreover, temperate peatlands are commonly exploited for agriculture (that is, grazing, arable crops), energy (that is, peat cutting and extraction), horticulture, and water resources, making it difficult to predict gas fluxes from these environments based on models of near-pristine northern peatlands (Charman 2002; Limpens and others 2008; Service 2007).

Past attempts to investigate greenhouse gas fluxes in managed peatlands have focussed on single gases (for example, $\mathrm{CH}_{4}$ or $\mathrm{CO}_{2}$ or $\mathrm{N}_{2} \mathrm{O}$ ), or pairs of compounds (for example, $\mathrm{CH}_{4}$ and $\mathrm{CO}_{2}$ ) (Hendriks and others 2007; Jungkunst and Fiedler 2007; Limpens and others 2008). Nitrous oxide fluxes have been particularly neglected, even though emissions from agricultural peatlands may be substantial (Jungkunst and Fiedler 2007; Langeveld and others 1997; Regina and others 2004; Schils and others 2006; Takakai and others 2006). Nitrous oxide fluxes were largely ignored in the past because conceptual models of peatland biogeochemistry are based on N-poor northern bogs (Limpens and others 2008). However, there has been growing interest in quantifying $\mathrm{N}_{2} \mathrm{O}$ fluxes from managed peatlands, in recognition of the fact that agricultural peatlands may have enhanced $\mathrm{N}$ pools and cycling rates due to fertilization or manure additions by livestock, increasing the potential for $\mathrm{N}_{2} \mathrm{O}$ fluxes (Jungkunst and Fiedler 2007; Langeveld and others 1997; Regina and others 2004; Schils and others 2006; Takakai and others 2006).

Managed peatlands exhibit a high degree of both spatial and temporal variability in greenhouse gas fluxes due to dynamic patterns in soil moisture, redox, and substrate availability, driven by human modifications of peatland hydrology and vegetation (Schrier-Uijl and others 2009; Strack and Waddington 2007, 2008; Waddington and Price 2000; Chen and others 2008; Inubushi and others 2003; Hendriks and others 2007; Fowler and others 1995a; Ward and others 2007). Patterning of peatland landscapes, for example, through the introduction of drainage ditches and managed agricultural fields often drives extreme differences in the composition and magnitude of greenhouse gases fluxes by significantly altering redox dynamics at the micro- and mesotope scale (Schrier-Uijl and others 2009, 2010; Strack and Waddington 2007). Common approaches for estimating greenhouse gas fluxes include eddy co-variance measurements, which provide an integrated picture of whole-ecosystem gas exchange, or static flux chambers, which facilitate identification of within-ecosystem variability. Both measurement techniques have inherent strengths and weakness; static chamber measurements better represent spatially heterogeneous gas fluxes, whereas eddy covariance techniques yield quasi-continuous measurements that are spatially integrated (Hendriks and others 2010; Schrier-Uijl and others 2010; Smith and others 1994). Most studies have relied on single measurement techniques (for example, static flux chambers or eddy covariance) to quantify greenhouse gas exchange, leading to potentially large uncertainties in ecosystem greenhouse gas budgets (Hendriks and others 2010; Schrier-Uijl and others 2010; Smith and others 1994).

Here, we quantified greenhouse gas fluxes from a mid-latitude drained peatland in the SacramentoSan Joaquin River Delta, California, USA (hereafter simply "the Delta"), currently managed as rangeland (that is, pasture). We used a multi-scale approach that combined static flux chambers, eddy covariance (for $\mathrm{CH}_{4}$ and $\mathrm{CO}_{2}$ only), and spatially weighted upscaling; techniques that allowed us to capture the "hotspots" and "hot moments" characteristic of greenhouse gas fluxes (sensu McClain 
and others 2003). The Delta is the largest estuary on the Pacific coast of the Americas, and is under multiple ecological and environmental pressures, including considerable flood risk from a failing levee system and continued land subsidence due to the decomposition of peat, soil compaction, and wind erosion (Florsheim and Dettinger 2007; Mount and Twiss 2005; Service 2007). Delta peatlands are the primary conduit for urban and agricultural water for the state of California, and have experienced extensive conversion to agriculture. Prior to the California Gold Rush, the Delta consisted of over $1400 \mathrm{~km}^{2}$ of unmanaged peatland, interspersed by several hundred kilometers of natural waterways (Service 2007; Drexler and others 2009). Extensive human settlement began in the 1860s, with farmers establishing levees and drainage ditches to make Delta peatlands more suitable for the cultivation of arable crops and livestock (Service 2007). Peatland drainage and water management have led to high rates of soil $\mathrm{C}$ mineralization and massive land subsidence, with Delta soils now up to $10 \mathrm{~m}$ below sea level (Deverel and Rojstaczer 1996; Miller and others 2000).

This study explores greenhouse gas fluxes, C sequestration, and global warming potential in a managed temperate peatland. We investigated the global warming potential of a drained temperate peatland under current agricultural management practices in the Delta, and the role of different greenhouse gases (that is, $\mathrm{CH}_{4}, \mathrm{CO}_{2}, \mathrm{~N}_{2} \mathrm{O}$ ) in regulating overall ecosystem global warming potential. We determined how greenhouse gas fluxes vary among representative landforms and the role of spatial and temporal heterogeneity in overall ecosystem gas exchange and trace gas budgets. We also explored the role of environmental variables (for example, climate, soil moisture, and so on) in mediating gas fluxes. Findings from this study provide the first steps to answering broader, more integrative questions about the effects of human activity on soil $\mathrm{C}$ sequestration, greenhouse gas fluxes, and the global warming potential of managed temperate peatlands. This research also provides an empirical basis for understanding the potential contributions of these ecosystems to local and regional greenhouse gas budgets.

\section{Methods ANd Materials}

\section{Study Site}

Flux measurements were conducted in a peatland pasture on Sherman Island $(38.04 \mathrm{~N}, 121.75 \mathrm{~W})$. Observations were collected over 60 weeks, from
10 April 2007 to 28 May 2008, in an area covering approximately $0.38 \mathrm{~km}^{2}$ and managed as rangeland for over 20 years (Figure 1). Approximately $49 \%$ of the land area on Sherman Island is currently under rangeland (US Department of Agriculture 2007). The climate is Mediterranean, with rain falling predominantly during the cool winter months (November to February). Mean annual rainfall is $325 \mathrm{~mm}$ and mean annual temperature is $15.6^{\circ} \mathrm{C}$. Historically, Sherman Island was planted with arable crops such as asparagus, corn, milo (sorghum), sugarbeet, barley, wheat, and potatoes (US Department of Agriculture 2007). The plant community at our site is dominated by two non-native, non-aerenchymatous invasive species: pepperweed (Lepidium latifolium L.), a perennial herb; and mouse barley (Hordenum murinum), an annual forage grass. Soils are classified as fine, mixed, superactive, thermic Cumulic Endoaquolls, consisting of a 25-92 cm of oxidized layer overlaying a 151$292-\mathrm{cm}$ thick organic peat horizon (Drexler and others 2009). Water table depths range from 30 to $70 \mathrm{~cm}$ below the soil surface, and are maintained by an active system of pumps and drainage ditches (Deverel and others 2007).

\section{Chamber Fluxes}

Static chamber measurements were used to investigate the effects of microform $(\sim 1-5 \mathrm{~m})$ to mesotope $(\sim 100 \mathrm{~m}-1 \mathrm{~km})$ scale variations in vegetation, hydrology, and redox potential on greenhouse gas fluxes $\left(\mathrm{CH}_{4}, \mathrm{CO}_{2}, \mathrm{~N}_{2} \mathrm{O}\right)$. Prior to the start of the experiment proper, we conducted a pilot study that sampled from all the major microforms and mesotopes in the study site, to evaluate overall patterns of spatial heterogeneity (ten 60-m long transects; $n=5$ static flux chamber per transect; $n=50$ static flux measurements). Using these preliminary data as a guide, static flux chambers were deployed in five $60-\mathrm{m}$ long transects representative of the dominant microforms and mesotopic features and sampled at weekly intervals (Figure 1). These landforms were categorized as "crown" $(n=5$ chambers), "slope" ( $n=5$ chambers), "hummock/ hollow" ( $n=10$ chambers), or "drainage ditch" ( $n=5$ chambers). Crown landforms are at least 500 $\mathrm{m}^{2}$ in size and possess either a slight convexity, or no apparent slope. Rainfall and groundwater tend to drain relatively quickly from these areas (typically within 1-3 days), leading to little or no surface water ponding. Slope areas are at least $500 \mathrm{~m}^{2}$ in size, with a gentle slope $(\sim 0.001 \%)$, and typically lie down gradient from crown landforms, draining water from these higher topographic features. 


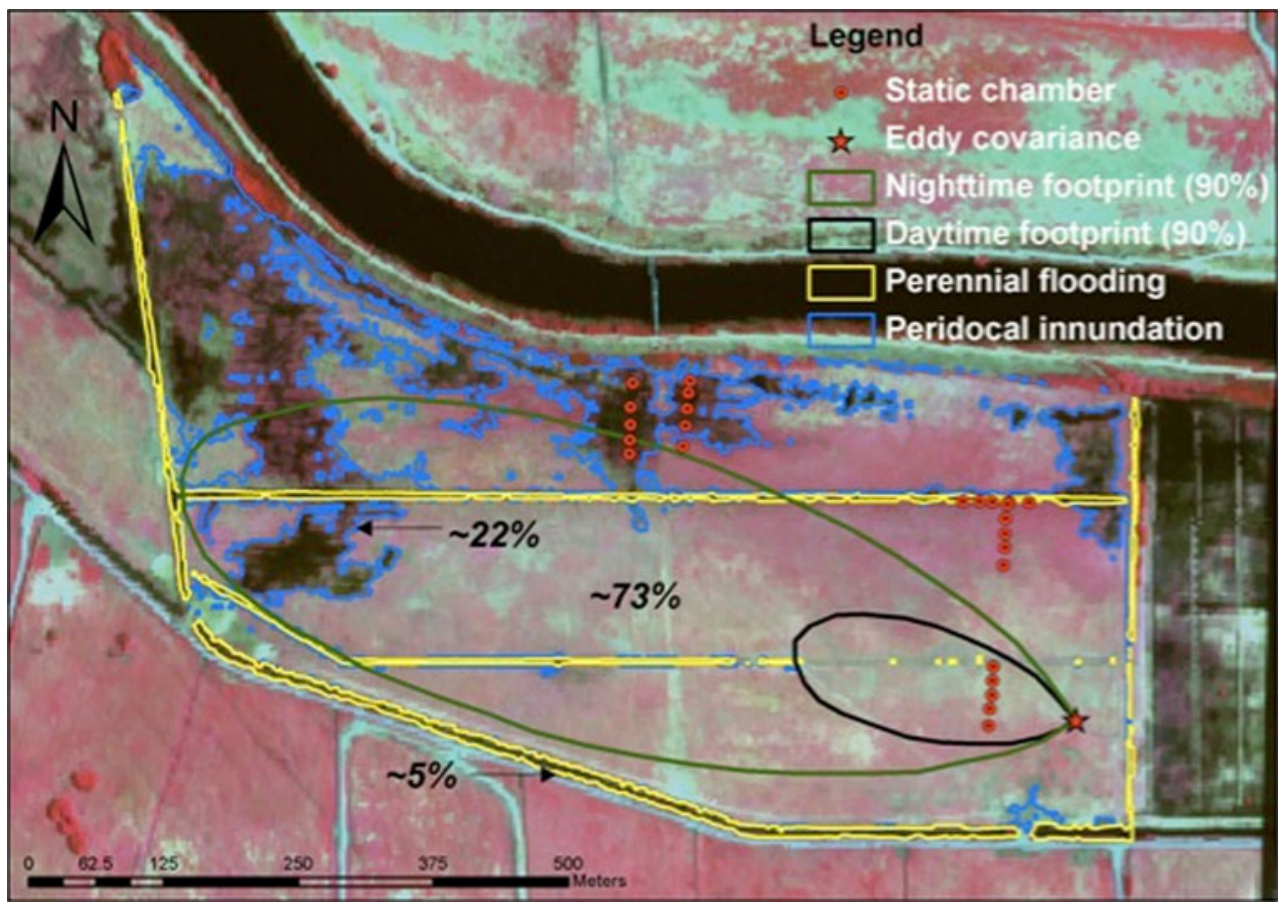

Figure 1. Remote sensing imagery of agricultural peatlands on Sherman Island. Airborne hyperspectral imager (HyMap) false-color composite (R;G;B: band 27 [near-infrared]; band 16 [red]; band 9 [green]) indicating flooding extent (dark areas) at the time of image acquisition. Overlayed are the locations of the static flux chambers, eddy covariance tower, and the tower footprint (night and day). Also represented on the image are the mapped areas (and their fractions) with different land surface wetness conditions (negligible surface water ponding [ 73\%], periodical inundation [ 22\%], perennial flooding $[\sim 5 \%])$ used to calculate spatially weighted seasonal and annual trace gas fluxes. (Color figure online)

Hummock/hollow areas are located in lower topographic positions, and contain complexes of shallow pools and very small knolls $(<10-\mathrm{cm}$ high), with each feature no more than $100 \mathrm{~m}^{2}$ (typically $\sim 25 \mathrm{~m}^{2}$ ) in size. These landforms are periodically inundated because of water management practices, or due to water draining from further upslope. Drainage ditches are common manmade features on farmed Delta islands and are used to remove water from the plant rooting zone to provide more suitable growing conditions for arable crops or pasture grasses (Deverel and others 2007). These landforms are perennially flooded.

Static chamber measurements were made by enclosing a $0.05-\mathrm{m}^{2}$ area with an opaque, 2-component (that is, base and lid) vented chamber for 30 minutes; headspace samples were collected using a gas-tight syringe at five time points. Static chambers were grounded (that is, not floating) in all landforms. Water levels in the drainage ditches were sufficiently low throughout the study period (5-10-cm depth) that floating chambers were not required. Chamber bases were inserted to a depth of about $5 \mathrm{~cm}$ in the soil of crown, slope, and hummock/hollow landforms and to a depth of about $1 \mathrm{~cm}$ in drainage ditch sediment. Gas samples were stored in pre-evacuated $10-\mathrm{ml}$ glass bottles sealed with Geo-Microbial Technologies septa (Geo-Microbial Technologies Inc., Ochelata, Oklahoma, USA), and analyzed for $\mathrm{CH}_{4}, \mathrm{CO}_{2}$, and $\mathrm{N}_{2} \mathrm{O}$ using a Shimadzu GC-14A gas chromatograph (Shimadzu Scientific Inc., Columbia, Maryland, USA), equipped with a Porapak-Q column, flame ionization detector (FID), thermal conductivity detector (TCD), and electron capture detector (ECD). The global warming potentials for $\mathrm{CH}_{4}$ and $\mathrm{N}_{2} \mathrm{O}$ were converted to $\mathrm{CO}_{2}$ equivalents by multiplying $\mathrm{CH}_{4}$ and $\mathrm{N}_{2} \mathrm{O}$ fluxes by 25 and 298, respectively (Forster and others 2007; Repo and others 2009; Frolking and Roulet 2007). These scaling factors represent the global warming potential for $\mathrm{CH}_{4}$ and $\mathrm{N}_{2} \mathrm{O}$ over a 100-year time horizon.

Carbon dioxide and $\mathrm{N}_{2} \mathrm{O}$ fluxes were calculated by applying a linear least squares regression to the chamber headspace concentration of each gas plotted against time $(P<0.05)$. Methane fluxes were calculated by different methods, depending on whether diffusion or ebullition was deemed to be the principal transport pathway. Diffusion was assumed to be the dominant physical transport 
pathway in chambers showing a linear change in $\mathrm{CH}_{4}$ concentrations over time, and fluxes calculated using a linear least squares approach $(P<0.05)$. Ebullition was assumed to be the dominant transport mechanism in chambers where $\mathrm{CH}_{4}$ concentrations showed either steep non-linear increases over time, or abrupt stochastic increases over time. Ebullition fluxes were calculated in one of two ways: for chambers showing steep non-linear increases, we fitted the data to a quadratic regression equation $(P<0.05)$, and fluxes were determined from the steep initial rise in $\mathrm{CH}_{4}$ concentrations. For chambers showing abrupt stochastic increases, fluxes were determined by calculating the total $\mathrm{CH}_{4}$ production over the entire enclosure period; a method that likely underestimates ebullition fluxes. Chamber data that did not meet any of these criteria were reported as net-zero fluxes.

\section{Eddy Covariance}

Eddy covariance measurements were employed to determine the temporal variability of spatially integrated ecosystem $\mathrm{CH}_{4}, \mathrm{CO}_{2}$ and $\mathrm{H}_{2} \mathrm{O}$ vapor fluxes (Baldocchi 2003; Detto and others 2010a). Nitrous oxide fluxes were only measured using the static flux chamber approach. Methane concentrations were determined using an off-axis integrated cavity output spectroscopy analyzer (Fast Methane Analyzer, Los Gatos Research, Inc, Mountain View, California, USA). Carbon dioxide and $\mathrm{H}_{2} \mathrm{O}$ vapor fluxes were measured with an open-path, infrared absorption gas analyzer (model LI-7500, LICOR, Lincoln, Nebraska, USA) (Baldocchi 2003), which was tested extensively at this study site and others to ensure optimal performance (Detto and others 2010a, b). Wind velocities and air temperature were also measured using a 3D sonic anemometer. All measurements were acquired at $10 \mathrm{~Hz}$ from a tower $3.15 \mathrm{~m}$ above the ground and data stored on a portable field computer. Vertical fluxes were computed on 30-min average windows, and corrected for tilt angles, temperature, and water vapor fluctuation effects (Detto and Katul 2007). Gaps due to data loss and quality check filtering were filled using a trained Artificial Neural Network (Papale and Valentini $2003)$. Cows $(\sim 100)$ were an irregular presence at this site. An automated digital camera (or "cow cam") was used to record the presence of cows in the tower footprint, omitting eddy covariance data when cows congregated near the tower base (primarily) at night, as this generated elevated flux estimates. The data reported here thus do not include the direct influence of ruminant respiration when cows were in the immediate vicinity of the tower, although more distal ruminant fluxes (that is, outside of the immediate tower precinct) were captured by our measurements.

\section{Environmental Variables}

To determine the effects of physical factors on trace gas dynamics, we measured air temperature, soil temperature, rainfall, soil moisture, and water table depth close to the tower in the crown zone. Air temperature and humidity were measured with an aspirated and shielded thermistor and capacitance sensor (Vaisala Inc, Vantaa, Finland). Rainfall was determined using a Texas Electronics (Texas Electronics Inc., Dallas, Texas, USA) tipping bucket rain gauge. Soil temperature was monitored continuously throughout the soil profile using copperconstantan thermocouples at 2, 4, 8, 16, 32, and 50 $\mathrm{cm}$ ( $n=3$ per depth). Volumetric soil moisture content (VWC; reported in percent) was measured using TDR probes (Delta-T Devices Ltd, Cambridge, UK) at $0-15,15-30,30-45$ and $45-60 \mathrm{~cm}(n=6$ per depth). The water table was measured with a pressure sensor (GE Druck Ltd, USA) immersed in a well next to the meteorological tower. Point measurements were also collected at weekly intervals from the $0-10-\mathrm{cm}$ depth during static flux chamber sampling to determine soil temperatures and soil moisture (reported either as percent VWC or percent water-filled pore space, the latter abbreviated as WFPS) in the immediate volume beneath each flux chamber. Weekly averages of soil temperature and moisture were calculated using continuous data collected in the tower footprint and point measurements collected during weekly chamber sampling.

\section{Spatially Weighted Extrapolations of Chamber Fluxes}

Two different airborne remote sensing data products of very high spatial resolution were used to determine the fractions of areas with different land surface wetness conditions on Sherman Island, including light detection and ranging (LiDAR), with a $1-m$ resolution, and hyperspectal imaging (HyMap) (Cocks and others 1998), with a 3-m resolution. Land surfaces were categorized as having "negligible surface water ponding" (dry drainage ditches, crown and slope), "periodical inundation" (hummock/hollow), or "perennial flooding" (wet drainage ditches). The drainage ditches were mapped on the basis of a LiDAR-derived digital elevation model (DWR 2009), with a simple decision tree 
classifier incorporating ground surface elevation and two topographic indices (slope, profile convexity) using the ENVI image processing environment. The area of periodic inundation was derived as flooding extent present at the time of HyMap image acquisition (Hestir and others 2008) using ISODATA unsupervised classification in the ENVI image-processing environment. The areal fractions were used to calculate spatially weighted seasonal and annual trace gas fluxes. Total daily and annual fluxes were obtained through linear interpolation of weekly static chamber measurements. Standard errors for the annual greenhouse gas budgets were calculated as follows: first, mean daily fluxes $(n=365)$ were calculated for each static flux chamber. Standard errors for each land surface wetness condition were subsequently determined from these mean daily fluxes. Finally, to calculate the standard error for the annual greenhouse gas budgets, spatial weightings were applied to each of the three land surface wetness conditions based on their respective areal fractions. These standard errors do not account for any uncertainty introduced by the pre-processing of the airborne remote sensing data, or through misclassification of the land surface wetness conditions.

\section{Statistics}

Statistical analyses were performed using JMP IN Version 8 (SAS Institute, Inc., Cary, North Carolina, USA). The data were log transformed whenever necessary to meet the assumptions of analysis of variance. Residuals for all analyses were checked for normality and homogeneity of variances. We used repeated-measures analysis of variance (ANOVA) to explore temporal trends in chamber fluxes and ANOVA to explore spatial patterns for normally distributed data. Kruskal-Wallis non-parametric ANOVA was used to explore spatial patterns for data that were not normally distributed. Bivariate and multiple regressions were employed to evaluate the relationship between continuous environmental variables and trace gas fluxes. Statistical significance was determined at the $P<0.05$ level, unless otherwise noted. Means comparisons were performed using Fisher's Least Significant Difference test (Fisher's LSD). Methane, $\mathrm{N}_{2} \mathrm{O}$, and $\mathrm{CO}_{2}$ fluxes from static chambers were used to explore spatial and temporal patterns across landforms. We report spatially extrapolated $\mathrm{CH}_{4}$ and $\mathrm{N}_{2} \mathrm{O}$ fluxes from static chambers as an estimate of net ecosystem-scale fluxes, because soils are considered the primary source of these gases; descriptions of our methodology and error estimation are provided above. We report the net ecosystem exchange of $\mathrm{CO}_{2}$ (NEE) using the eddy covariance data, which incorporates plant uptake and respiration. We also compared static chamber estimates of soil respiration with overlapping night time ecosystem respiration $\left(R_{\mathrm{ECO}}\right)$, the majority of which is derived from soils. Values are reported as means and standard errors ( $\pm 1 \mathrm{SE})$.

\section{RESUlts}

\section{Net Ecosystem Trace Gas Fluxes}

During the first year, the peatland pasture was a net source of $\mathrm{CH}_{4}$ and $\mathrm{N}_{2} \mathrm{O}$ (Figure 2), and approached net balance for $\mathrm{CO}_{2}$ with the atmosphere (near-zero NEE; Figures 2, 3). Both spatially weighted extrapolations of static flux chamber measurements and eddy covariance indicated that the ecosystem was a net source of atmospheric $\mathrm{CH}_{4}$. Spatially weighted chamber measurements, averaged across all landforms, yielded a mean daily soil flux of $25.8 \pm$ $1.4 \mathrm{mg} \mathrm{CH}_{4}-\mathrm{C} \mathrm{m}^{-2} \mathrm{~d}^{-1}$, whereas daytime eddy covariance measurements averaged $5.6 \pm 0.3 \mathrm{mg}$ $\mathrm{CH}_{4}-\mathrm{C} \mathrm{m}^{-2} \mathrm{~d}^{-1}$ (Figure 2A). Annual soils emissions were estimated to be $9.5 \pm 3.4 \mathrm{~g} \mathrm{CH}_{4}-\mathrm{C} \mathrm{m}^{-2} \mathrm{y}^{-1}$ based on chamber measurements, or $1.6 \pm 1.4 \mathrm{~g}$ $\mathrm{CH}_{4}-\mathrm{C} \mathrm{m}^{-2} \mathrm{y}^{-1}$ by eddy covariance. Soil $\mathrm{N}_{2} \mathrm{O}$ fluxes were consistently very high. Spatially weighted extrapolations of chamber fluxes averaged $6.4 \pm 0.4$ $\mathrm{mg} \mathrm{N}_{2} \mathrm{O}-\mathrm{N} \mathrm{m}^{-2} \mathrm{~d}^{-1}$ (Figure $2 \mathrm{C}$ ). Overall annual $\mathrm{N}_{2} \mathrm{O}$ emissions for the first year of observations were $2.4 \pm 1.3 \mathrm{~g} \mathrm{~N}_{2} \mathrm{O}-\mathrm{N} \mathrm{m}^{-2-1}$.

Spatially weighted chamber measurements indicated an average daily soil respiration rate of $5.9 \pm 0.3 \mathrm{~g} \mathrm{CO}_{2}-\mathrm{C} \mathrm{m}^{-2} \mathrm{~d}^{-1}$; and were greater than soil respiration estimated from night time eddy covariance fluxes (that is, ecosystem respiration, $\left.R_{\mathrm{ECO}}\right)$, which yielded an average flux of $3.9 \pm 0.2 \mathrm{~g}^{-} \mathrm{C} \mathrm{m}^{-2} \mathrm{~d}^{-1}$ (Figure 2B). A large proportion of photosynthetic $\mathrm{C}$ uptake was lost to the atmosphere via respiration, such that NEE approached net balance with the atmosphere (Figure 3A). Eddy covariance measurements indicated that from 10 April 2007 to 9 April 2008, overall NEE was only a meagre $-8.4 \mathrm{~g} \mathrm{C} \mathrm{m}^{-2} \mathrm{y}^{-1}$; that is, close to $\mathrm{CO}_{2}$-neutrality (Figure $3 \mathrm{~A}$ ).

\section{Spatial and Temporal Variability in Gas Exchange}

\section{Methane Emissions}

Methane fluxes showed high spatial variability, but few or no temporal trends (Figures 2A, 3B; Table 1). $\mathrm{CH}_{4}$ fluxes varied significantly by a factor 

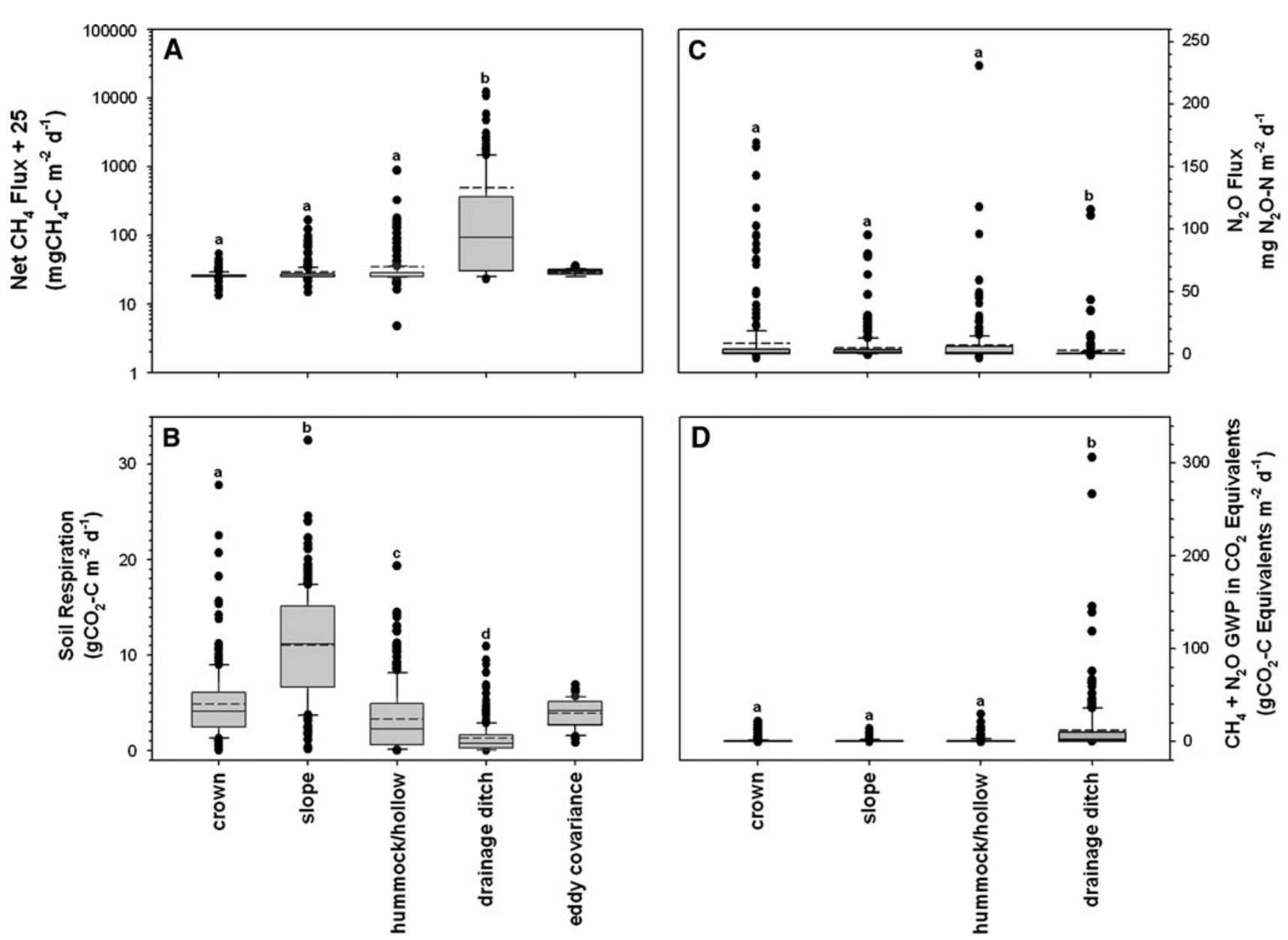

Figure 2. Net fluxes of $\mathbf{A ~} \mathrm{CH}_{4}, \mathbf{B}$ soil respiration, $\mathbf{C ~} \mathrm{N}_{2} \mathrm{O}$, and $\mathbf{D} \mathrm{CH}_{4}$ and $\mathrm{N}_{2} \mathrm{O}$ expressed as global warming potential in $\mathrm{CO}_{2}$ equivalents for different landforms in the drained peatland pasture on Sherman Island. Eddy covariance observations are shown for comparison. In (A), 25 was added to the raw $\mathrm{CH}_{4}$ flux data so that negative or zero net fluxes could be logtransformed. The short-dash line within each box represents the mean, whereas the solid line represents the median. Boxes enclose the interquartile range, whiskers indicate the 90th and 10th percentiles. Lower case letters indicate statistically significant differences among means (Fisher's LSD, $P<0.05$ ).

of up to 400 or more among landforms (KruskalWallis, $P<0.0001$; Figure $2 \mathrm{~A}$; Table 1). Multiple comparison tests indicated that $\mathrm{CH}_{4}$ fluxes from drainage ditches greatly exceeded that of all other landforms by up to two orders of magnitude (466.4 $\pm 78.4 \mathrm{mg} \mathrm{CH}_{4}-\mathrm{C} \mathrm{m}^{-2} \mathrm{~d}^{-1}$ ); in comparison, hummock/hollow areas emitted $9.5 \pm 3.4 \mathrm{mg}$ $\mathrm{CH}_{4}-\mathrm{C} \mathrm{m}^{-2} \mathrm{~d}^{-1}$, slopes emitted $3.9 \pm 0.9 \mathrm{mg} \mathrm{CH}_{4}-\mathrm{C}$ $\mathrm{m}^{-2} \mathrm{~d}^{-1}$ and crown landforms emitted $1.0 \pm$ $0.2 \mathrm{mg} \mathrm{CH}_{4}-\mathrm{C} \mathrm{m}^{-2} \mathrm{~d}^{-1}$. Methane fluxes between individual hummock and hollow microforms were not significantly different from each other in this ecosystem, unlike other peatlands (Belyea and Baird 2006; Pelletier and others 2007; Waddington and Roulet 1996), and we grouped the data from these two microforms together. Eddy covariance measurements of net $\mathrm{CH}_{4}$ exchange showed an inverse relationship with mean weekly soil temperature $\left(r^{2}=0.32, P<0.0001\right)$, a weak positive correlation with mean weekly VWC $\left(r^{2}=0.20, P<0.01\right)$ and mean weekly WFPS $\left(r^{2}=0.19, P<0.01\right)$.

\section{Nitrous Oxide Dynamics}

Nitrous oxide fluxes varied by a factor of 3 or more among landforms $\left(F_{3,916}=13.6, P<0.0001\right.$; Figure 2C; Table 1). Multiple comparisons tests indicated that the highest $\mathrm{N}_{2} \mathrm{O}$ fluxes were from crown landforms $\left(8.7 \pm 1.7 \mathrm{mg} \mathrm{N}_{2} \mathrm{O}-\mathrm{N} \mathrm{m}^{-2} \mathrm{~d}^{-1}\right)$ and hummock/hollow $\left(7.1 \pm 1.4 \mathrm{mg} \mathrm{N} \mathrm{N}_{2} \mathrm{O}-\mathrm{N} \mathrm{m}^{-2} \mathrm{~d}^{-1}\right)$ areas. Slopes had intermediate levels of $\mathrm{N}_{2} \mathrm{O}$ flux $\left(5.0 \pm 0.8 \mathrm{mg} \mathrm{N}_{2} \mathrm{O}-\mathrm{N} \mathrm{m}^{-2} \mathrm{~d}^{-1}\right)$, whereas drainage ditches had the lowest emissions $(2.6 \pm$ $0.9 \mathrm{mg} \mathrm{N}_{2} \mathrm{O}-\mathrm{N} \mathrm{m}^{-2} \mathrm{~d}^{-1}$ ). Slopes and hummock/ 

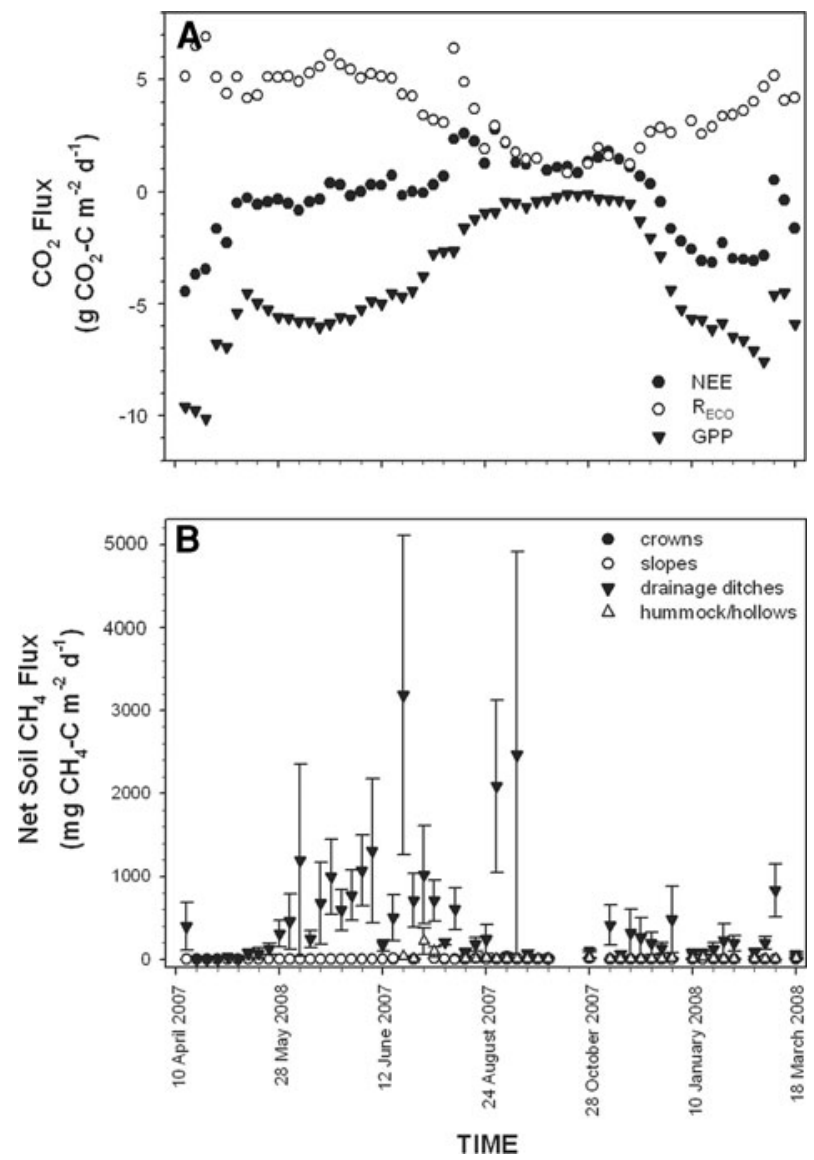

Figure 3. Temporal variations in ecosystem $\mathrm{CO}_{2}$ fluxes (A) and $\mathrm{CH}_{4}$ fluxes from different landforms (B). Panel $\mathbf{A}$ shows net ecosystem exchange (NEE), ecosystem respiration $\left(R_{\mathrm{ECO}}\right)$ and gross primary productivity (GPP) determined by eddy covariance measurements. Panel B shows $\mathrm{CH}_{4}$ fluxes determined by chamber measurements. Bars indicate standard errors.

hollows showed little or no change in $\mathrm{N}_{2} \mathrm{O}$ emissions over time, whereas crowns and drainage ditches fluctuated due to changes in soil temperature and water-filled porosity driven by seasonality and management $\quad\left(F_{72,916}=3.3, \quad P<0.0001\right) . \quad \mathrm{N}_{2} \mathrm{O}$ fluxes in crowns were positively correlated with
WFPS $\left(r^{2}=0.55, P<0.0001\right.$; Figure 6A), weakly correlated with water table depth $\left(r^{2}=0.25\right.$, $P<0.01)$, weakly correlated rainfall $\left(r^{2}=0.15\right.$, $P<0.01$ ), and negatively correlated with soil temperature $\left(r^{2}=0.54, P<0.0001\right.$; Figure 6B). Episodic rainfall in winter increased soil moisture and WFPS, increasing $\mathrm{N}_{2} \mathrm{O}$ fluxes from crowns; whereas fluctuations in WFPS due to water management practices lowered or raised $\mathrm{N}_{2} \mathrm{O}$ fluxes from drainage ditches. A multiple regression model using these drivers explained $64 \%(P<0.0001)$ of the variability in the data. Nitrous oxide fluxes in hummock/hollows were also weakly positively correlated to water table depth $\left(r^{2}=0.30\right.$, $P<0.0001)$ and rainfall $\left(r^{2}=0.12, P<0.01\right)$, with a multiple regression model explaining only $36 \%(P<0.0001)$ of the overall variability in the data. Nitrous oxide fluxes from drainage ditches were positively correlated with WFPS $\left(r^{2}=0.35\right.$, $P<0.0001$ ), although insensitive to variations in other environmental variables. Nitrous oxide fluxes from slopes showed no response to fluctuations in WFPS, rainfall, water table depth, or temperature.

\section{Soil and Ecosystem $\mathrm{CO}_{2}$ Fluxes}

Chamber measurements of soil respiration also indicated high spatial variability (Figure 2B). Fluxes varied significantly among landforms by up to an order of magnitude $\left(F_{3,1012}=307.3\right.$, $P<0.0001$; Fisher's LSD, $P<0.05$; Figure 2B; Table 1), with crowns emitting $4.9 \pm 0.2 \mathrm{~g} \mathrm{CO}_{2}-\mathrm{C}$ $\mathrm{m}^{-2} \mathrm{~d}^{-1}$, slopes emitting $11.0 \pm 0.2 \mathrm{~g} \mathrm{CO}_{2}-\mathrm{C} \mathrm{m}^{-2}$ $\mathrm{d}^{-1}$, hummock/hollow areas emitting $3.3 \pm 0.2 \mathrm{~g}$ $\mathrm{CO}_{2}-\mathrm{C} \mathrm{m}^{-2} \mathrm{~d}^{-1}$, and drainage ditches emitting $1.3 \pm 0.2 \mathrm{~g} \mathrm{CO}_{2}-\mathrm{C} \mathrm{m}^{-2} \mathrm{~d}^{-1}$.

Unlike $\mathrm{CH}_{4}$, soil $\mathrm{CO}_{2}$ fluxes were affected by seasonal variations in soil moisture, rainfall, and temperature. Soil respiration was negatively correlated with soil WFPS when all chamber data were pooled $\left(r^{2}=0.51, P<0.0001\right.$; Figure $\left.4 \mathrm{~A}\right)$, as was $R_{\mathrm{ECO}}\left(r^{2}=0.46, P<0.0001 ;\right.$ Figure $\left.4 \mathrm{~B}\right)$. Disaggregating the chamber data and analyzing the

Table 1. Net Trace Gas Fluxes by Land Form

\begin{tabular}{lcccr}
\hline Landform & $\begin{array}{l}\mathrm{CH}_{4} \\
\left(\mathrm{mg} \mathrm{CH}_{4}-\mathrm{C} \mathrm{m}^{-2} \mathrm{~d}^{-1}\right)\end{array}$ & $\begin{array}{l}\mathrm{CO}_{2} \\
\left(\mathrm{~g} \mathrm{CO}_{2}-\mathrm{C} \mathrm{m}^{-2} \mathrm{~d}^{-1}\right)\end{array}$ & $\begin{array}{l}\mathrm{N}_{2} \mathrm{O} \\
\left(\mathrm{g} \mathrm{N}_{2} \mathrm{O}-\mathrm{N} \mathrm{m}^{-2} \mathrm{~d}^{-1}\right)\end{array}$ & $\begin{array}{l}\mathrm{CH}_{4}+\mathrm{N}_{2} \mathrm{O} \mathrm{GW}^{\text {equivalents }}(\mathrm{g} \\
\text { equivalents }\end{array}$ \\
\hline Crown & $1.0 \pm 0.2 \mathrm{a}$ & $4.9 \pm 0.2 \mathrm{a}$ & $8.7 \pm 1.7 \mathrm{a}$ & $1.0 \pm 1.0 \mathrm{a}$ \\
Slope & $3.9 \pm 0.9 \mathrm{a}$ & $11.0 \pm 0.2 \mathrm{~b}$ & $5.0 \pm 0.8 \mathrm{a}$ & $0.7 \pm 1.0 \mathrm{a}$ \\
Hummock/hollow & $9.5 \pm 3.4 \mathrm{a}$ & $3.3 \pm 0.2 \mathrm{c}$ & $7.1 \pm 1.4 \mathrm{a}$ & $1.0 \pm 1.0 \mathrm{a}$ \\
Drainage ditch & $466.4 \pm 78.4 \mathrm{~b}$ & $1.3 \pm 0.2 \mathrm{~d}$ & $2.6 \pm 0.9 \mathrm{~b}$ & $12.0 \pm 1.0 \mathrm{~b}$
\end{tabular}




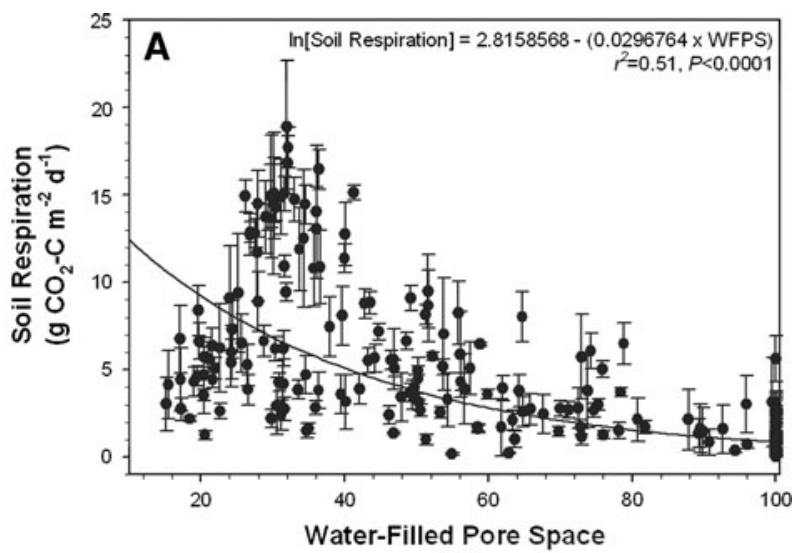

$(\%)$

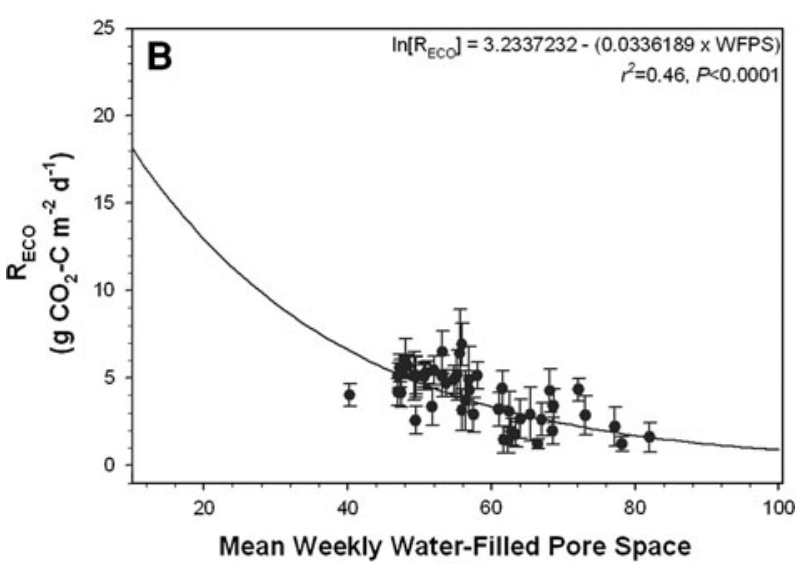

$(\%)$

Figure 4. Soil respiration, as determined by chamber measurements, plotted against soil moisture (A) and ecosystem respiration $\left(R_{\mathrm{ECO}}\right)$, as determined by eddy covariance measurements, plotted against soil moisture (B). In panel A, each data point represents the mean of five replicate flux chambers. In panel $\mathbf{B}$, weekly averaged values of $R_{\mathrm{ECO}}$ are plotted against weekly averaged values of WFPS for the entire peatland. Bars indicate standard errors.

response of individual landforms indicated that slopes $\left(r^{2}=0.61, P<0.0001\right)$ and hummock/hollows $\left(r^{2}=0.39, P<0.0001\right)$ had the strongest responses to changing soil moisture, whereas crowns and drainage ditches did not appear to respond to soil moisture. Soil respiration was negatively correlated with rainfall in slope $\left(r^{2}=0.52, P<\right.$ $0.0001)$, hummock/hollow $\left(r^{2}=0.23, P<0.0001\right)$, and crown $\left(r^{2}=0.20, P<0.0001\right)$ landforms, although eddy covariance data showed no overall effect of mean weekly rainfall on $R_{\mathrm{ECO}}$. Tower measurements showed a strong positive relationship between $R_{\mathrm{ECO}}$ and mean weekly soil temperature $\left(r^{2}=0.77, P<0.0001\right.$; Figure 5). Analysis of the chamber soil respiration measurements indicated that individual landforms responded

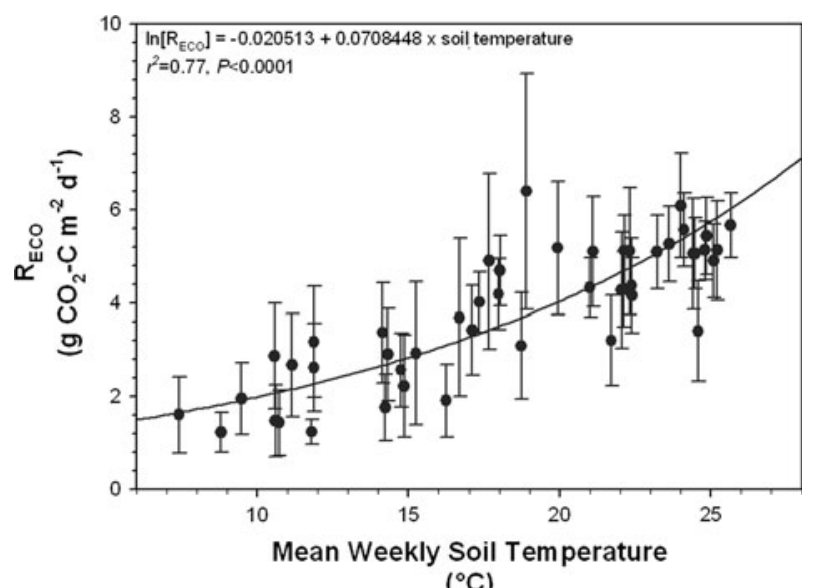

$\left({ }^{\circ} \mathrm{C}\right)$

Figure 5. Ecosystem respiration $\left(R_{\mathrm{ECO}}\right)$, as determined by eddy covariance measurements, plotted against soil temperature. Each data point represents weekly-averaged values of both $R_{\mathrm{ECO}}$ and soil temperature. Bars indicate standard errors.

differently to seasonal fluctuations in temperature. Soil respiration on slopes, for example, was much more closely correlated with temperature $\left(r^{2}=\right.$ 0.52, $P<0.0001)$ than other landforms, such as crowns and hummock/hollows (both $r^{2}=0.17$, $P<0.05)$; whereas drainage ditches showed no temperature response whatsoever.

The chamber data were subsequently analyzed using multiple regression models that included WFPS, rainfall, and temperature as driving variables. A multiple regression model using all the chamber data pooled together explained $56 \%$ of the variability in the data set $(P<0.0001)$. Multiple regression models applied to data disaggregated by landform indicated that WFPS, rainfall, and temperature together explained $76 \%(P<$ $0.0001)$ of the overall variability in the respiration rates of slopes, $56 \%(P<0.0001)$ of the variability in hummock/hollows, and $25 \%(P<0.01)$ of the variability in crowns.

Eddy covariance measurements of NEE, gross primary productivity (GPP), and $R_{\mathrm{ECO}}$ indicated strong seasonal trends in ecosystem-scale $\mathrm{CO}_{2}$ fluxes, largely driven by changes in plant activity and modulated by fluctuations in soil respiration (Figure 3A). Net ecosystem exchange values were negative (that is, net $\mathrm{CO}_{2}$ uptake) in spring and summer 2007. Over autumn, NEE became gradually more positive, shifting toward a net $\mathrm{CO}_{2}$ source during winter. Gross primary productivity followed a similar pattern (Figure 3A), with peak GPP during spring-summer, declining GPP during autumn, and near-cessation of plant $\mathrm{C}$ uptake during winter. Ecosystem respiration had slightly different 


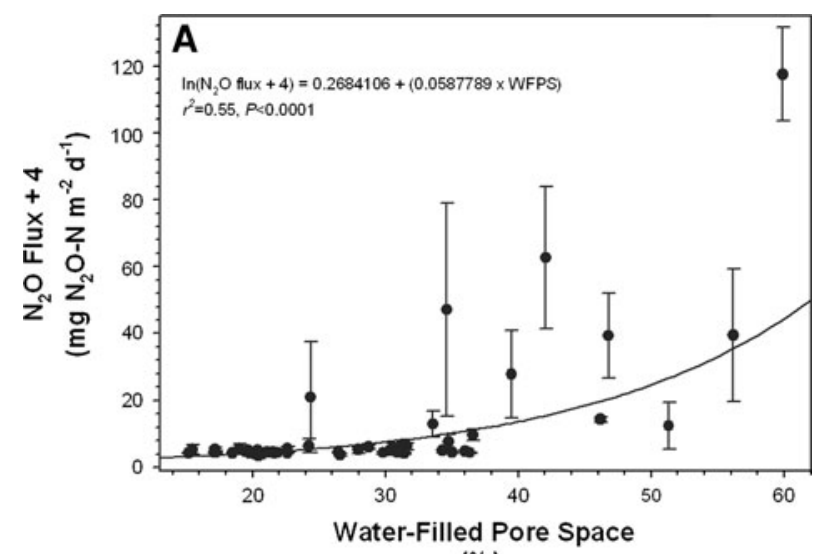

$(\%)$

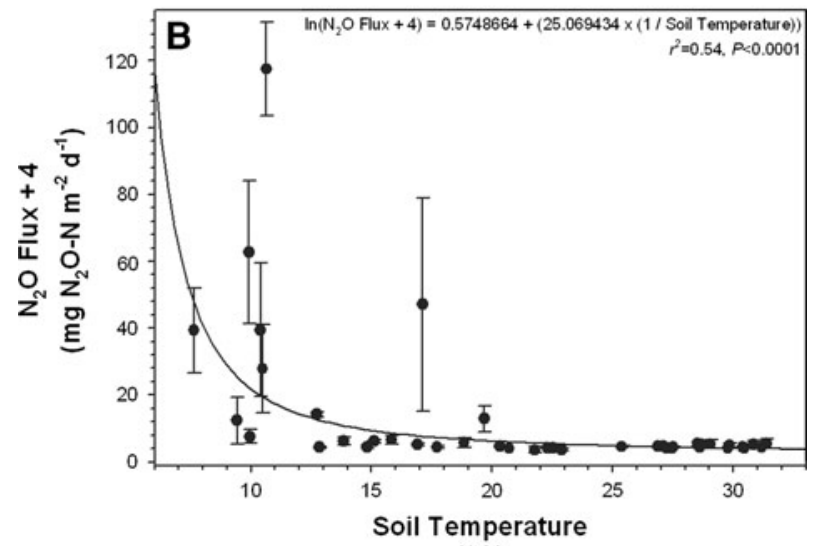

$\left({ }^{\circ} \mathrm{C}\right)$

Figure 6. Nitrous oxide fluxes plotted against soil moisture $(\mathbf{A})$ and soil temperature $(\mathbf{B})$ for crown landforms. In both the panels, four was added to the raw $\mathrm{N}_{2} \mathrm{O}$ fluxes so that net negative or zero fluxes could be log-transformed. Each data point represents the mean of five replicate flux chambers. Bars indicate standard errors.

seasonal dynamics (Figure 3A), influenced by fluctuations in soil temperature (Figure 5). Ecosystem respiration rates remained relatively stable through spring-summer 2007, before steadily declining throughout autumn 2007, reaching an annual minima during winter (Figure 3A). Ecosystem respiration subsequently rose again during spring 2008, as soil temperature increased (Figure 3A, 5).

Net ecosystem exchange was closely correlated with GPP $\left(r^{2}=0.72, P<0.0001\right)$ and only weakly correlated with $R_{\mathrm{ECO}}\left(r^{2}=0.10, P<0.01\right)$, suggesting that GPP drove overall patterns of NEE. Net ecosystem exchange also showed a weak negative correlation with mean weekly soil temperature $\left(r^{2}=0.22, P<0.001\right)$ and a weak positive correlation with mean weekly WFPS $\left(r^{2}=0.17\right.$, $P<0.01)$. Gross primary productivity was also negatively correlated with mean weekly soil temperature $\left(r^{2}=0.60, P<0.0001\right)$ and positively correlated with mean weekly WFPS $\left(r^{2}=0.42\right.$, $P<0.0001)$.

\section{Ecosystem Global Warming Potential}

The measured global warming potential of this peatland was $530.8 \pm 188.5 \mathrm{~g} \mathrm{CO}_{2}$-C equivalents $\mathrm{m}^{-2} \mathrm{y}^{-1}$, based on eddy covariance measurements of NEE and spatially extrapolated chamber fluxes of $\mathrm{CH}_{4}$ and $\mathrm{N}_{2} \mathrm{O}$. The global warming potential of $\mathrm{CH}_{4}$ and $\mathrm{N}_{2} \mathrm{O}$ fluxes entirely offset the $\mathrm{CO}_{2}$ uptake by photosynthesis, with an equivalent of $236.8 \pm 85.5 \mathrm{~g} \mathrm{CO}_{2}$ - $\mathrm{C}$ equivalents $\mathrm{m}^{-2} \mathrm{y}^{-1}$ and $302.4 \pm 168.0 \mathrm{~g} \mathrm{CO}_{2}$-C equivalents $\mathrm{m}^{-2} \mathrm{y}^{-1}$ released to the atmosphere from soil $\mathrm{CH}_{4}$ and $\mathrm{N}_{2} \mathrm{O}$ emissions, respectively.

\section{Discussion}

\section{Methane Emissions}

Methane fluxes from this ecosystem were high for arable land, contributing to regional climate warming (that is, $9.5 \pm 3.4 \mathrm{~g} \mathrm{CH}_{4}-\mathrm{C} \mathrm{m}^{-2} \mathrm{y}^{-1}$ ). This inference is independently supported by tall tower atmospheric measurements, which indicate that managed Delta peatlands are important regional sources of greenhouse gases (Zhao and others 2009). Soil $\mathrm{CH}_{4}$ fluxes for this ecosystem exceeded those for other managed temperate peatlands, including those managed for forestry (Fowler and others 1995a), grazing or dairy farming (Schrier-Uijl and others 2009; Jungkunst and Fiedler 2007), or controlled drying experiments (Strack and Waddington 2007). Drainage and management activities likely decreased $\mathrm{CH}_{4}$ emissions relative to unmanaged, "pristine" peatlands through drying of surface peats, enhancing the size of the oxic (that is, $\mathrm{CH}_{4}$-oxidizing) zone, while simultaneously diminishing the size and activity of anoxic (that is, methanogenic) horizons (Strack and Waddington 2007; Moore and Roulet 1993). Elevated soil $\mathrm{CH}_{4}$ fluxes stem from emission "hotspots" in the landscape (that is, drainage ditches) and anaerobic decomposition of the underlying peat beneath the water table. One shortcoming of our chamber-based approach is that we probably underestimated ecosystem $\mathrm{CH}_{4}$ exchange by excluding bovine fluxes. Bovine emissions are potentially quite large; using the per capita emission rates reported in the literature, we estimated that a herd of a similar size to that grazing our study site ( 100 cows) could emit as much as 10$40 \mathrm{~g} \mathrm{CH}_{4}-\mathrm{C} \mathrm{m}^{-2} \mathrm{y}^{-1}$ (Laubach and Kelliher 2005; Laubach and others 2008; McGinn and others 2009; Shibata and Terada 2010; Shaw and others 
2007). However, bovine fluxes were difficult to estimate because cows were an irregular presence in our study site.

Discrepancies between chamber and tower measurements of $\mathrm{CH}_{4}$ flux ultimately stem from the spatial heterogeneity of $\mathrm{CH}_{4}$ sources across the landscape, combined with the size and shape of the daytime tower footprint (Detto and others 2010a). During the day, the tower footprint only captured $\mathrm{CH}_{4}$ fluxes from drier uplands immediately adjacent to the tower, and did not adequately sample from drainage ditches and hummock/hollows (that is, higher $\mathrm{CH}_{4}$-emitting landforms), which were more distally located (Figure 1). Because these drier areas were very weak or near-zero $\mathrm{CH}_{4}$ sources, the correlation between static chamber and eddy covariance measurements was very poor when we compared chamber measurements from within the daytime tower footprint against eddy covariance fluxes. Due to the complex, heterogeneous distribution of $\mathrm{CH}_{4}$-sources across the landscape and aseasonality of $\mathrm{CH}_{4}$ fluxes, the spatially weighted upscaling of chamber fluxes probably better represents ecosystem $\mathrm{CH}_{4}$ fluxes than eddy covariance measurements for this site.

Methane fluxes showed greater spatial, rather than temporal heterogeneity. Overall soil $\mathrm{CH}_{4}$ emissions were driven by aseasonal "hotspots" of biological activity. Despite the fact that drainage ditches accounted for less than $5 \%$ of the land area, they contributed more than $84 \%$ of $\mathrm{CH}_{4}$ emissions and more than $37 \%$ of ecosystem global warming potential. Fluxes from these $\mathrm{CH}_{4}$ hotspots showed little or no seasonal variability, presumably because drainage ditches are perennially wet and stably anoxic, with a relatively abundant supply of labile organic matter (Deverel and others 2007). Other $\mathrm{CH}_{4}$-emitting landforms (for example, hummock/ hollows, slopes, crowns) also showed little or no temporal variability in fluxes, probably because water table depth, soil moisture, and WFPS probably did not vary enough throughout the year to cause dynamic changes in the activity of methanotrophic and methanogenic microsites (Jungkunst and Fiedler 2007). The weak inverse relationship between net $\mathrm{CH}_{4}$ fluxes and mean weekly temperature detected by the eddy covariance tower is puzzling because we did not observe a similar pattern in the chamber data. One explanation for this is that $\mathrm{CH}_{4}$ oxidation was slightly enhanced during warmer periods in the immediate footprint of the tower, decreasing net $\mathrm{CH}_{4}$ fluxes. The chamber measurements may not have detected this trend, because it was highly localized to the area immediately adjacent to the tower, rather than a more system-wide phenomena.

\section{Nitrous Oxide Dynamics}

Nitrous oxide fluxes from this peatland were large; equal to or greater than those from heavily fertilized agricultural systems and tropical forests, which are the two largest $\mathrm{N}_{2} \mathrm{O}$ sources worldwide (Matson and Vitousek 1990; Perez and others 2001). These very high $\mathrm{N}_{2} \mathrm{O}$ fluxes were probably sustained by the input of manure, agricultural run-off, and fertilizer application, all of which increase $\mathrm{N}$ throughput via nitrification or denitrification (Flessa and others 1998; Furukawa and others 2002; Inubushi and others 2003; Regina and others 2004; Service 2007). In addition, colonization of the site by the invasive alien pepperweed (Lepidium latifolium L.) may have also enhanced $\mathrm{N}_{2} \mathrm{O}$ fluxes because this species is known to increase soil $\mathrm{N}$ turnover and throughput (Blank and Youn 2002).

Nitrous oxide fluxes were more homogeneously distributed across the landscape than $\mathrm{CH}_{4}$ fluxes, with the highest emissions coming from drier landforms. Nitrous oxide fluxes were greatest from crowns, hummock/hollows, and slopes, which together comprised more than $95 \%$ of the land area. Nitrous oxide fluxes were more responsive to changes in environmental conditions than $\mathrm{CH}_{4}$ fluxes, although $\mathrm{N}_{2} \mathrm{O}$ fluxes at the ecosystem scale were relatively aseasonal. Only crown landforms responded to seasonal fluctuations in WFPS and soil temperature. Although drainage ditches also responded to changes in WFPS, these fluctuations were driven by management practices rather than by seasonal water dynamics.

In the crowns and drainage ditches, the positive relationship between $\mathrm{N}_{2} \mathrm{O}$ fluxes and WFPS (Figure 6A) implies that denitrification was the dominant $\mathrm{N}_{2} \mathrm{O}$-producing process in these landforms (Smith and others 1998; Bateman and Baggs 2005); an inference supported by follow-up studies using denitrification enzyme assays and stable isotope tracers to partition $\mathrm{N}_{2} \mathrm{O}$ sources (Yang and others 2011). In the crowns, the negative correlation between $\mathrm{N}_{2} \mathrm{O}$ fluxes and soil temperature (Figure 6B) probably reflects the drying effects of warmer surface soil temperatures, rather than direct temperature-inhibition of $\mathrm{N}_{2} \mathrm{O}$ production. Although crown landforms $\left(21.1 \pm 0.5^{\circ} \mathrm{C}\right.$ in the $0-10-\mathrm{cm}$ depth) were significantly warmer than the others (15.5 $\pm 0.2^{\circ} \mathrm{C}$ in the $0-10$-cm depth), temperatures were not high enough to directly inhibit nitrification or denitrification (Barnard and others 2005; 
Smith and others 1998). Soil temperatures, however, were negatively correlated with WFPS, with soil temperatures above $16^{\circ} \mathrm{C}$ driving WFPS below $35 \%\left(r^{2}=0.49, P<0.001\right)$; the critical moisture threshold below which $\mathrm{N}_{2} \mathrm{O}$ production from nitrification becomes increasingly substrate-limited (Bateman and Baggs 2005; Stark and Firestone 1995). Analysis of the frequency distribution of the soil temperature and moisture data indicated that surface soils were above $16^{\circ} \mathrm{C}$ and less than $35 \%$ WFPS for more than $75 \%$ of the year, indicating that even this high $\mathrm{N}_{2} \mathrm{O}$ production by nitrification or denitrification was probably constrained by substrate availability or by redox conditions for most of the observation period.

\section{Soil and Ecosystem $\mathrm{CO}_{2}$ Fluxes}

Although NEE for April 2007 to May 2008 approached net $\mathrm{CO}_{2}$-neutrality (Sonnentag and others 2010), the continual loss of $C$ from this peatland has lead to massive land subsidence and soil compaction, suggesting that respiration outpaces plant C-fixation over longer time scales (Drexler and others 2009; Ingebritsen and other 2000; Miller and others 2000; Rojstaczer and Deverel 1993; Rojstaczer and Deverel 1995; Service 2007). This inference is supported by subsequent eddy covariance measurements conducted at this field site since the completion of this study, which indicates that the site is a net $\mathrm{CO}_{2}$ source over the mediumto long-term, with interannual variability in fluxes modulated by management activities (Baldocchi and others, unpublished).

Soil $\mathrm{CO}_{2}$ fluxes from this ecosystem were very high, with respiration rates that were comparable to fluxes from humid tropical forests, which have the greatest soil respiration rates globally (Raich and Schlesinger 1992). These high soil respiration rates were sustained by microbial oxidation of the underlying peat, combined with vigorous autotrophic respiration during the growing season (Deverel and Rojstaczer 1996; Miller and others 2000). Soil respiration rates were slightly higher from static chambers than soil respiration estimated from night time eddy covariance measurements, although the two were strongly positively correlated $\left(r^{2}=0.70, P<0.0001\right)$. This discrepancy is likely the result of $\mathrm{CO}_{2}$ storage due to nocturnal thermal stratification, or cooler temperatures lowering plant and microbial respiration at night (Baldocchi 2003).

Of the three greenhouse gases, $\mathrm{CO}_{2}$ shows the greatest seasonal variability, driven primarily by plant responses to seasonal fluctuations in soil moisture and temperature. Photoassimilation rates (GPP) determined the overall direction (that is, source or sink) and magnitude of ecosystem $\mathrm{CO}_{2}$ exchange (NEE), with peak periods of plant productivity in spring and summer leading to an overall draw down of atmospheric $\mathrm{CO}_{2}$. Soil temperature and moisture play an important role in regulating GPP during the growing season, as demonstrated by the strong negative correlation between GPP and temperature $\left(r^{2}=0.60\right.$, $P<0.0001$; that is, increasing soil temperature promoting greater $\mathrm{C}$ uptake), and the positive correlation between GPP and WFPS $\left(r^{2}=0.42\right.$, $P<0.0001$ ). During quiescent periods (that is, late autumn or winter), $\mathrm{CO}_{2}$ was emitted to the atmosphere as soil respiration gradually outpaced photosynthesis.

Soil respiration in this ecosystem was simultaneously regulated by soil moisture and temperature. Increases in WFPS following winter storms or due to water management led to reductions in soil respiration, suggesting that soil $\mathrm{CO}_{2}$ fluxes in this ecosystem may be transport-limited (Smith and others 2003; Teh and others 2005). Soil temperature, on the other hand, was positively correlated with soil respiration rates, suggesting that cooler temperatures during spring, autumn, and winter limited the overall metabolic activity of plant roots and soil microbes.

One important pathway for C loss that we did not explore in this study was aquatic $C$ export (Deverel and others 2007; Deverel and Rojstaczer 1996). Losses of dissolved gases (that is, "gas evasion" sensu Billett and others 2004), dissolved organic $\mathrm{C}$ (DOC), and particulate organic C (POC) often represent a significant $C$ loss from peatlands (Billett and others 2004; Hope and others 2001; Limpens and others 2008; Deverel and others 2007; Deverel and Rojstaczer 1996). Measurements of DOC fluxes from Delta peatlands, including Sherman Island, suggest annual soil losses on the order of 5-110 g C m ${ }^{-2} \mathrm{y}^{-1}$, which roughly translates to $0.4-8 \%$ of the GPP, or $0.4-9 \%$ of $R_{\mathrm{ECO}}$ on Sherman Island (Deverel and others 2007; Deverel and Rojstaczer 1996). This is a lower figure than for other temperate peatlands, where DOC exports typically account for at least $10 \%$ of ecosystem $C$ outputs (Limpens and others 2008). However, because GPP $\left(-1352.9 \mathrm{~g} \mathrm{C} \mathrm{m}^{-2} \mathrm{y}^{-1}\right)$ and $R_{\mathrm{ECO}}\left(1266.6 \mathrm{~g} \mathrm{~m}^{-2}\right.$ $\mathrm{y}^{-1}$ ) were so evenly matched from April 2007 to May 2008, additional C losses from aquatic exports could very well tip the balance between $C$ inputs and outputs, shifting the ecosystem from net balance toward a net C source (Billett and others 
2004; Hope and others 2001; Limpens and others 2008).

\section{Ecosystem Global Warming Potentials}

The overall global warming potential of this ecosystem (530.8 $\mathrm{g} \mathrm{CO}_{2}$-C equivalents $\mathrm{m}^{-2} \mathrm{y}^{-1}$ ) was high when compared to other managed temperate peatlands in Europe and North America, where global warming potentials typically range from 100 to $500 \mathrm{~g} \mathrm{CO}_{2}-\mathrm{C}$ equivalents $\mathrm{m}^{-2} \mathrm{y}^{-1}$ (Hendriks and others 2007; Langeveld and others 1997; Schils and others 2006; Strack and Waddington 2007; Frolking and Roulet 2007). The greater global warming potential of this drained peatland was probably due to a combination of warmer conditions and very high $\mathrm{N}_{2} \mathrm{O}$ fluxes. Mean annual temperature in the Delta is $15.6^{\circ} \mathrm{C}$; roughly $5-6^{\circ} \mathrm{C}$ warmer than other temperate field sites where comparable studies have been performed (Hendriks and others 2007; Langeveld and others 1997; Schils and others 2006; Strack and Waddington 2007; Carroll and Crill 1997). Likewise, $\mathrm{N}_{2} \mathrm{O}$ fluxes at this site were as much as an order of magnitude greater than emissions from other managed temperate peatlands (Jungkunst and Fiedler 2007; Langeveld and others 1997; Regina and others 2004; Schils and others 2006), effectively shifting global warming potentials to higher values. Methane and $\mathrm{N}_{2} \mathrm{O}$ emissions offset any ecosystem $\mathrm{C}$ gains made by plant $\mathrm{C}$-fixation throughout the year, with consistently high, aseasonal fluxes of $\mathrm{CH}_{4}$ and $\mathrm{N}_{2} \mathrm{O}$ nullifying the atmospheric cooling effects of photoassimilation, even during peak periods of plant activity.

\section{ConClusions AND IMPLICATIONS FOR MANAgeMENT}

The high global warming potential of these temperate agricultural peatlands suggests that they are regionally important sources of greenhouse gases; an inference supported by inverse atmospheric measurements of greenhouse gas fluxes for central California (Zhao and others 2009). The high global warming potential of this peatland is ultimately driven by emissions of non- $\mathrm{CO}_{2}$ greenhouse gases (that is, $\mathrm{CH}_{4}, \mathrm{~N}_{2} \mathrm{O}$ ). These data suggest that changes in soil moisture associated with water management practices or future climate change could have important ramifications for the global warming potential of these managed peatlands. The increased abundance of persistent, perennially flooded patches in wetter years, or under less intensive drainage could greatly enhance $\mathrm{CH}_{4}$ emissions, whereas relatively modest increases in soil moisture could amplify $\mathrm{N}_{2} \mathrm{O}$ fluxes from drier landforms. Because the potential for $\mathrm{CH}_{4}$ and $\mathrm{N}_{2} \mathrm{O}$ emissions from these soils is very large, changes in soil moisture or flooding extent need only take place over a small proportion of the landscape to dramatically increase overall ecosystem global warming potential.

\section{ACKNOWLEDGEMENTS}

Thanks are owed to K. Smetak, A.W. Thompson, T. Hehn and B. Runkle for assistance with fieldwork and laboratory analyses. Thanks are also owed to A.J.B., E.M.S., R.A.J.R. and J.-A.S. who provided comments on earlier drafts of this manuscript. This research was supported by a grant from the US National Science Foundation awarded to D.D.B., W.L.S. and M.K., and a NSF sub-award to Y.A.T. (NSF-ATM 0628720). This publication is a contribution from the Scottish Alliance for Geoscience, Environment, and Society (http://www.sages.ac.uk).

\section{OPEN ACCESS}

This article is distributed under the terms of the Creative Commons Attribution Noncommercial License which permits any noncommercial use, distribution, and reproduction in any medium, provided the original author(s) and source are credited.

\section{REFERENCES}

Baldocchi DD. 2003. Assessing the eddy covariance technique for evaluating carbon dioxide exchange rates of ecosystems: past, present and future. Glob Change Biol 9:479-92.

Barnard R, Leadley PW, Hungate BA. 2005. Global change, nitrification, and denitrification: a review. Global Biogeochem Cycles 19:1-13.

Bateman EJ, Baggs EM. 2005. Contributions of nitrification and denitrification to $\mathrm{N}_{2} \mathrm{O}$ emissions from soils at different waterfilled pore space. Biol Fertil Soils 41:379-88.

Belyea LR, Baird AJ. 2006. Beyond "The limits to peat bog growth": cross-scale feedback in peatland development. Ecol Monogr 76:299-322.

Billett MF, Palmer SM, Hope D, Deacon C, Storeton-west R, Hargreaves KJ, Flechard C, Fowler D. 2004. Linking landatmosphere-stream carbon fluxes in a lowland peatland system. Global Biogeochem Cycles 18:1-12.

Blank RR, Youn JA. 2002. Influence of the exotic invasive crucifer, Lepidium latifolium. on soil properties and elemental cycling. Soil Sci 167:821-9.

Carroll P, Crill P. 1997. Carbon balance of a temperate poor fen. Global Biogeochem Cycles 11:349-56.

Charman D. 2002. Peatlands and environmental change. Chichester: Wiley. 
Chen Y, Mcnamara NP, Dumont MG, Bodrossy L, Stralis-Pauese N, Murrell JC. 2008. The impact of burning and Calluna removal on below-ground methanotroph diversity and activity in a peatland soil. Appl Soil Ecol 40:291-8.

Cocks T, Jenssen R, Stewart A, Wilson I, Shields T. 1998. The HyMap (TM) airborne hyperspectral sensor: the system calibration and performance. Versailles: European Assoc Remote Sensing Laboratories.

Detto M, Katul GG. 2007. Simplified expressions for adjusting higher-order turbulent statistics obtained from open path gas analyzers. Boundary-Layer Meteorol 122:205-16.

Detto M, Baldocchi DD, Katul GG. 2010a. Scaling properties of biologically active scalar concentration fluctuations in the surface boundary layer over a managed peatland. BoundaryLayer Meteorol 136:407-30.

Detto M, Verfaillie J, Anderson F, Xu L, Baldocchi DD. $2010 \mathrm{~b}$. Comparing laser-based open- and closed-path gas analyzers to measure methane fluxes using the eddy covariance method. Agric For Meteorol (in review)

Deverel SJ, Rojstaczer S. 1996. Subsidence of agricultural lands in the Sacramento San Joaquin Delta, California: role of aqueous and gaseous carbon fluxes. Water Resour Res 32:2359-67.

Deverel SJ, Leighton DA, Finlay MR. 2007. Processes affecting agricultural drainwater quality and organic carbon loads in California's Sacramento-San Joaquin Delta. San Francisco Estuary Watershed Sci 5:1-25.

Dise NB. 2009. Peatland response to global change. Science $326: 810-11$.

Drexler JZ, de Fontaine CS, Deverel SJ. 2009. The legacy of wetland drainage on the remaining peat in the SacramentoSan Joaquin Delta, California, USA. Wetlands 29:372-86.

DWR. 2009. Land Use Survey Data. California Department of Water Resources, Division of Planning and Local Assistance.

Fiedler S, Holl BS, Jungkunst HF. 2005. Methane budget of a Black Forest spruce ecosystem considering soil pattern. Biogeochemistry 76:1-20

Flessa H, Wild U, Klemisch M, Pfadenhauer J. 1998. Nitrous oxide and methane fluxes from organic soils under agriculture. Eur J Soil Sci 49:327-35.

Florsheim JL, Dettinger MD. 2007. Climate and floods still govern California levee breaks. Geophys Res Lett 34:L22403, $1-5$.

Forster P, Ramaswamy V, Artaxo P, AL E. 2007. Chapter 2. Changes in atmospheric constituents and in radiative forcing. In: Solomon S, Qin D, Manning M, Chen Z, Marquis M, Averyt KB, Tignor M, Miller HL, Eds. Climate Change 2007: the physical science basis. Contribution of Working Group I to the fourth assessment report of the intergovernmental panel on climate change. Cambridge: Cambridge University Press.

Fowler D, Hargreaves KJ, Macdonald JA, Gardiner B. 1995a. Methane and $\mathrm{CO}_{2}$ exchange over peatland and the effects of afforestation. Forestry 68:327-34.

Fowler D, Hargreaves KJ, Skiba U, Milne R, Zahniser MS, Moncrieff JB, Beverland IJ, Gallagher MW. 1995b. Measurements of $\mathrm{CH}_{4}$ and $\mathrm{N}_{2} \mathrm{O}$ fluxes at the landscape scale using micrometeorological methods. Philos Trans R Soc Lond a 351:339-55.

Frolking S, Roulet N. 2007. Holocene radiative forcing impact of northern peatland carbon accumulation and methane emissions. Glob Change Biol 13:1079-88.
Furukawa Y, Inubushi K, Ali M, Itang AM, Tsuruta H. 2002. Effect of changing groundwater levels caused by land-use changes on greenhouse gas fluxes from tropical peat lands. International Workshop on Land-Use Change and Greenhouse Gases, Soil C and Nutrient Cycling in the Tropics. Tsukuba, Japan, Springer.

Hendriks DMD, van Huissteden J, Dolman AJ, van Der Molen MK. 2007. The full greenhouse gas balance of an abandoned peat meadow. Biogeosciences 4:411-24.

Hendriks DMD, Van Huissteden J, Dolman AJ. 2010. Multitechnique assessment of spatial and temporal variability of methane fluxes in a peat meadow. Agric For Meteorol. doi:10.1016/j.agrformet.2009.06.017.

Hestir EL, Khanna S, Andrew ME, Santos MJ, Viers JH, Greenberg JA, Rajapakse SS, Ustin SL. 2008. Identification of invasive vegetation using hyperspectral remote sensing in the California Delta ecosystem. Remote Sens Environ 112:403447.

Hope D, Palmer SM, Billett MF, Dawson JJC. 2001. Carbon dioxide and methane evasion from a temperate peatland stream. Limnol Oceanogr 46:847-57.

Ingebritsen SE, Ikehara ME, Galloway DL, Jones DR. 2000. Delta subsidence in California-the sinking heart of the state. U.S. Geological Survey.

Inubushi K, Furukawa Y, Hadi A, Purnomo E, Tsuruta H. 2003. Seasonal changes of $\mathrm{CO}_{2}, \mathrm{CH}_{4}$ and $\mathrm{N}_{2} \mathrm{O}$ fluxes in relation to land-use change in tropical peatlands located in coastal area of South Kalimantan. Chemosphere 52:603-8.

Jungkunst HF, Fiedler S. 2007. Latitudinal differentiated water table control of carbon dioxide, methane and nitrous oxide fluxes from hydromorphic soils: feedbacks to climate change. Glob Change Biol 13:2668-83.

Langeveld CA, Segers R, Dirks BOM, Vandenpolvandasselaar A Velthof GL, Hensen A. 1997. Emissions of $\mathrm{CO}_{2}, \mathrm{CH}_{4}$ and $\mathrm{N}_{2} \mathrm{O}$ from pasture on drained peat soils in the Netherlands. Eur J Agron 7:35-42.

Laubach J, Kelliher FM. 2005. Methane emissions from dairy cows: comparing open-path laser measurements to profilebased techniques. Agric For Meteorol 135:340-5.

Laubach J, Kelliher FM, Knight TW, Clark H, Molano G, Cavanagh A. 2008. Methane emissions from beef cattle-a comparison of paddock- and animal-scale measurements. Aust J Exp Agric 48:132-7.

Limpens J, Berendse F, Blodau C, Canadell JG, Freeman C, Holden J, Roulet N, Rydin H, Schaepman-Strub G. 2008. Peatlands and the carbon cycle: from local processes to global implications-a synthesis. Biogeosciences 5:1475-91.

Matson PA, Vitousek PM. 1990. Ecosystem approach to a global nitrous oxide budget. Bioscience 40:667-72.

McClain ME, Boyer EW, Dent CL, Gergel SE, Grimm NB, Groffman PM, Hart SC, Harvey JW, Johnston CA, Mayorga E, McDowell WH, Pinay G. 2003. Biogeochemical hot spots and hot moments at the interface of terrestrial and aquatic ecosystems. Ecosystems 6:301-12.

Mcginn SM, Beauchemin KA, Flesch TK, Coates T. 2009. Performance of a dispersion model to estimate methane loss from cattle in pens. J Environ Qual 38:1796-802.

Miller RL, Hastings L, Fujii R. 2000. Hydrological treatments affect gaseous carbon loss from organic soils, Twitchell Island, California, October 1995-December, 1997. US Geological Survey. 
Moore TR, Roulet NT. 1993. Methane flux: water table relations in Northern wetlands. Geophys Res Lett 20:587-90.

Mount J, Twiss R. 2005. Subsidence, sea-level rise, and seismicity in the Sacramento-San Joaquiin Delta. San Francisco Estuary Watershed Sci 3:1-18.

Papale D, Valentini A. 2003. A new assessment of European forests carbon exchanges by eddy fluxes and artificial neural network specialization. Glob Change Biol 9:525-35.

Pelletier L, Moore TR, Roulet NT, Garneau M, Beaulieu-Audy V. 2007. Methane fluxes from three peatlands in the La Grande Riviere watershed, James Bay lowland, Canada. J Geophys Res Biogeosci 112:12.

Perez T, Trumbore SE, Tyler SC, Matson PA, Ortiz-Monasterio I, Rahn T, Griffith DWT. 2001. Identifying the agricultural imprint on the global $\mathrm{N}_{2} \mathrm{O}$ budget using stable isotopes. $\mathrm{J}$ Geophys Res Atmos 106:9869-78.

Raich JW, Schlesinger WH. 1992. The global carbon dioxide flux in soil respiration and its relationship to vegetation and climate. Tellus B 44:81-99.

Regina K, Syvasalo E, Hannukkala A, Esala M. 2004. Fluxes of $\mathrm{N}_{2} \mathrm{O}$ from farmed peat soils in Finland. Eur J Soil Sci 55:591-9.

Repo M, Susiluoto S, Lind SA, Jokinen S, Elsakov V, Biasi C, Virtanen T, Martikainen PJ. 2009. Large $\mathrm{N}_{2} \mathrm{O}$ emissions from cryoturbated peat soil in tundra. Nature Geoscience 2:189-92.

Rojstaczer S, Deverel SJ. 1993. Time-dependence in atmospheric carbon inputs from drainage of organic soils. Geophys Res Lett 20:1383-6.

Rojstaczer S, Deverel SJ. 1995. Land subsidence in drained histosolos and highly organic mineral soils of California. Soil Sci Soc Am J 59:1162-7.

Schils RLM, Verhagen A, Aarts HFM, Kuikman PJ, Sebek LBJ. 2006. Effect of improved nitrogen management on greenhouse gas emissions from intensive dairy systems in the Netherlands. Glob Change Biol 12:382-91.

Schrier-Uijl AP, Kroon PS, Leffelaar PA, Van Huissteden JC, Berendse F, Veenendaal EM. 2009. Methane emissions in two drained peat agro-ecosystems with high and low agricultural intensity. Plant Soil. doi: 10.1007/s11104-009-0180-1.

Schrier-Uijl AP, Kroon PS, Hensen A, Leffelaar PA, Berendse F, Veenendaal EM. 2010. Comparison of chamber and eddy covariance-based $\mathrm{CO}_{2}$ and $\mathrm{CH}_{4}$ emission estimates in a heterogeneous grass ecosystem on peat. Agric For Meteorol 150:825-31.

Service RF. 2007. Delta Blues, California Style. Science 317: 442-5.

Shaw SL, Mitloehner FM, Jackson W, Depeters EJ, Fadel JG, Robinson PH, Holzinger R, Goldstein AH. 2007. Volatile organic compound emissions from dairy cows and their waste as measured by proton-transfer-reaction mass spectrometry. Environ Sci Technol 41:1310-16.

Shibata M, Terada F. 2010. Factors affecting methane production and mitigation in ruminants. Anim Sci J 81:2-10.

Smith KA, Clayton H, Arah JRM, Christensen S, Ambus P, Fowler D, Hargreaves KJ, Skiba U, Harris GW, Wienhold FG, Klemedtsson L, Galle B. 1994. Micrometeorological and chamber methods for measurement of nitrous oxide fluxes between soils and the atmosphere - overview and conclusions. J Geophys Res Atmos 99:16541-8.
Smith KA, Thomson PE, Clayton H, Mctaggart IP, Conen F. 1998. Effects of temperature, water content and nitrogen fertilisation on emissions of nitrous oxide by soils. Atmos Environ 32:3301-9.

Smith KA, Ball T, Conen F, Dobbie KE, Massheder J, Rey A. 2003. Exchange of greenhouse gases between soil and atmosphere: interactions of soil physical factors and biological processes. Eur J Soil Sci 54:779-91.

Sonnentag O, Detto M, Runkle BRK, Teh YA, Silver WL, Kelly M, Baldocchi DD. 2010. Carbon dioxide exchange of a pepperweed (Lepidium latifolium L.) infestation: how do flowering and mowing affect canopy photosynthesis and autotrophic respiration? J Geophys Res (G). doi: 10.1029/2010JG001522.

Stark JM, Firestone MK. 1995. Mechanisms for soil-moisture effects on activity of nitrifying bacteria. Appl Environ Microbiol 61:218-21.

Strack M, Waddington JM. 2007. Response of peatland carbon dioxide and methane fluxes to a water table drawdown experiment. Global Biogeochem Cycles. 21:GB1007. doi:10.1029/2006GB002715.

Strack M, Waddington JM. 2008. Spatiotemporal variability in peatland subsurface methane dynamics. J Geophys Resarch (G), 113:G02010. doi:10.1029/2007JG000472.

Takakai F, Morishita T, Hashidoko Y, Darung U, Kuramochi K, Dohong S, Limin SH, Hatano R. 2006. Effects of agricultural land-use change and forest fire on $\mathrm{N}_{2} \mathrm{O}$ emission from tropical peatlands, Central Kalimantan, Indonesia. Soil Sci Plant Nutr 52:662-74.

Teh YA, Silver W, Conrad M. 2005. Oxygen effects on methane production and oxidation in humid tropical forest soils. Glob Change Biol 11:1283-97. doi:10.1111/j.1365-2486.2005. 00983.

US Department Of Agriculture. 2007. 2007 California Cropland Data Layer: Land Cover Types at Sherman Island. USDA National Agricultural Statistics Service.

Waddington JM, Price JS. 2000. Effect of peatland drainage, harvesting, and restoration on atmospheric water and carbon exchange. Phys Geogr 21:433-51.

Waddington JM, Roulet NT. 1996. Atmosphere-wetland carbon exchanges: scale dependency of $\mathrm{CO}_{2}$ and $\mathrm{CH}_{4}$ exchange on the developmental topography of a peatland. Global Biogeochem Cycles 10:233-45.

Ward SE, Bardgett RD, Mcnamara NP, Adamson JK, Ostle NJ. 2007. Long-term consequences of grazing and burning on northern peatland carbon dynamics. Ecosystems 10:1069-83.

Yang WH, Teh YA, Silver WL. 2011. Nitrous oxide production and consumption in a drained peatland pasture: a test of a fieldbased $15 \mathrm{~N}$-nitrous oxide pool dilution technique (In prep).

Zhao C, Andrews AE, Bianco L, Eluszkiewicz J, Hirsch A, Macdonald C, Nehrkorn T, Fischer ML. 2009. Atmospheric inverse estimates of methane emissions from Central California. J Geophys Res 114:D16302.

Zona D, Oechel WC, Kochendorfer J, Paw U KT, Salyuk AN, Olivas PC, Oberbauer SF, Lipson DA. 2009. Methane fluxes during the initiation of a large-scale water table manipulation experiment in the Alaskan Arctic tundra. Global Biogeochem Cycles 23:1-11. 